\title{
Frieda Edelstein, Carmen Fenechiu \& Dana LaCourse Munteanu, Sintaxă latină. I. Sintaxa cazurilor, Presa Universitară Clujeană, Cluj-Napoca, 2012, 166 p.; II. Sintaxa modurilor, Presa Universitară Clujeană, Cluj-Napoca, 2014, 218 p.
}

\author{
Maria Aldea* \\ Facultatea de Litere, Universitatea „Babeș-Bolyai”, Str. Horea 31, 400202 Cluj-Napoca, România
}

Prin publicarea celor două volume consacrate Sintaxei latine, Frieda Edelstein, Carmen Fenechiu și Dana LaCourse Munteanu aduc în atenția publicului larg un domeniu care pe nedrept pierde teren, filologia clasică, și o disciplină lingvistică a acestuia, sintaxa, fără de care studiul sintaxei limbii române nu ar fi complet.

Avînd ca punct de pornire în demersul analitic și interpretativ „utilizarea distincției saussuriene signifiant, signifié la nivelul sintaxei latine (i.e. diferențierea formei de conținut în analiza relației sintactice), cît şi intenția de a prezenta materialul sintactic cît mai sistematic, prin căutarea și identificarea unor criterii unitare, care să fie consecvent aplicate în analiză" (p. 13), volumele aici prezentate, concepute ca instrumente de lucru, sînt destinate atît „studenților avansați, dar și profesorilor” cu scopul de a le pune la dispoziție „o lucrare clară și concisă dedicată sintaxei limbii latine" (p. 13).

Primul volum, consacrat sintaxei cazurilor, debutează cu o clarificare teoretică fundamentală înțelegerii obiectului de studiu al sintaxei, și anume relația sintactică. Concepută ca o legătură „între doi termeni ce formează un binom sau o structură binară” (p. 17), relația sintactică de coordonare sau de subordonare este esențială în interpretarea sintactică a faptelor de limbă, întrucît implică „două aspecte: conținut, care are în vedere natura legăturii stabilite (în cazul coordonării) sau funcția (=F) (în cazul subordonării) și formă, reprezentată prin mijlocul de expresie, marcă (=M).” (p. 17).
După prezentarea modului de realizare a relației de coordonare şi de subordonare (p. 17-24), autoarele iau în discuție acordul (p. 25-35), procedînd la taxonomia acestuia în funcție de două criterii: gradul de rigurozitate și extensia, distingînd, după expresia termenului subordonat, următoarea tipologie: acordul gramatical riguros, total; acordul gramatical riguros, parțial sau variația concomitentă; acordul gramatical total, prin atracție și acordul ad sensum.

În continuare, atenția lingvistelor se oprește asupra sistemului cazual latinesc. Aplicînd aceeaşi organizare sistematică în expunere, fiecare caz beneficiază de o informație etimologică succintă urmată de prezentarea structurilor sintagmatice și a funcțiilor generate însoțite de nu puține exemple ce „provin atît din gramaticile de specialitate, cît și din lecturile autoarelor. Poeții și prozatorii latini ale căror opere constituie baza materialului faptic sînt cei îndeosebi studiați în cadrul orelor de latină: pentru perioada arhaică: Plautus și Terentius, pentru perioada republicană: Cæsar, Cicero și Sallustius, pentru perioada augustană și imperială: Vergilius, Horatius, Titus Livius şi Tacitus. Incursiunile în epocile creștină și medievală vor fi puține și numai atunci cînd sînt absolut necesare pentru înțelegerea evoluției sintactice" (p. 13).

Reținem pentru cazul nominativ (p. 37-41) că „din punctul de vedere al conținutului funcțional, el este cazul subiectului, al numelui predicativ și al apoziţiei” (p. 37), avînd însă atît „statut de ordin 1, cît și de ordin 2 sau $2^{\prime \prime \prime}$ (p. 37). Cu statutul de

\footnotetext{
*Adresă de corespondență: aldea_maria@yahoo.com.

${ }^{1}$ Se cuvine menționat că, în maniera de prezentare a funcțiilor sintactice, lingvistele își raportează analiza la modelul propus de D.D. Draşoveanu referitor la taxonomia cazurilor.

Este bine știut că, în concepția lui D.D. Drașoveanu, categoria cazului cunoaște, după criteriul gradului de funcționalitate, trei ipostaze sau ordine: (1) cazuri de ordinul I (sau cazuri flexionale) ce le cuprind „pe cele manifestate în substantive și pronume, unde ele înseși, cazurile, sînt generatoare de funcții” (în nominativ - subiect, nume predicativ, element predicativ suplimentar și falsă apoziție; în acuzativ - complement direct, complement de timp, atribut și element predicativ suplimentar; în dativ - complement indirect, complement de loc și atribut; în genitiv - atribut genitival); (2) cazuri de ordinul II, și anume „cazurile angajate prin (de către) acord,
} 
caz de ordin $2^{\prime}$, acesta realizează și funcția de element predicativ suplimentar care „nu se află în dublă subordonare, neexistînd marcă a subordonării față de verb" $^{2}$ (p. 38). În ceea ce privește vocativul (p. 43), se constată că „este întîlnit singur, caz de ordin 1 , fără funcție sintactică și fără statut de $\operatorname{Tr}^{3}$ [termen regent, nota noastră - M.A.], dar sînt atestate şi situații în care el este regent pentru un V2 [vocativ de ordin 2, nota noastră - M.A.] cu funcție de atribut adjectival" (p. 43). O atenție aparte este acordată genitivului (p. 45-68). Dacă din punct de vedere sincronic genitivul adnominal cunoaște o frecvență ridicată, interpretarea faptelor de limbă din perspectivă diacronică ridică probleme referitor „la cronologia termenului regent și implicit la funcția îndeplinită” (p. 45) de acesta. După unii cercetători, „funcția originară și proprie a genitivului rezidă în faptul că el determina mai îndeaproape conținutul unui substantiv", în timp ce pentru alții, genitivul a beneficiat la început de o întrebuințare adverbală. Referitor la dativ (p. 6982), autoarele remarcă existența în literatura de specialitate a două direcții privind funcțiile realizate: pe de o parte, e considerat "cazul complementului indirect” și, pe de altă parte, este negată această funcție: „În primul caz, absolutizarea creează unele confuzii, pentru că dativul poate îndeplini și alte funcții (precum cea de complement circumstanțial de scop sau de atribut) [...]. În cel de-al doilea caz, eliminarea funcției de complement indirect duce la imprecizii și inconsecvențe, la nedeterminarea con- ținutului funcțional al anumitor relații, respectiv la considerarea diverselor specii sau valori drept funcții.” (p. 69). În ceea ce privește acuzativul (p. 83126), autoarele atrag atenția asupra traducerii greșite a denumirii cazului, apreciind că acesta ar trebui să se numească „causativus casus”, întrucît denumește „ceea ce sau cel ce este cauzat” (p. 83). Expunînd punctual numeroasele valori sintactice ale acestuia, lingvistele caută să evidențieze pentru fiecare valoare detașată „termenii regenți, deoarece, pe de o parte, se cîștigă astfel în consecvență, iar, pe de altă parte, se poate urmări mai clar relația ce se instituie între $\mathrm{Tr}$ - Ts [termenul regent - termenul subordonat, nota noastră - M.A.] și funcția sintactică realizată de acuzativ.” (p. 83). În continuare, atenția acestora se fixează asupra locativului (p. 127-128) și ablativului (p. 129-163). Dacă pentru primul cercetătoarele constată că „Locativul indo-european nu s-a păstrat în perioada istorică cu desinențe specifice decît la temele în $-a,-o /-e[\ldots]$ (izolat la temele în consoană)" (p. 127), putînd fi reperat în perioada preclasică cu precădere în folosirea lui domi, ruri (p. 127), dar și în alte substantive sau în numele de orașe, cu ablativul se produce o răsturnare, deoarece acest caz „[...] prezintă cele mai numeroase funcții și specii în raport cu celelalte cazuri din limba latină, ceea ce nu este deloc surprinzător ținînd cont de faptul că provine din sincretismul a trei cazuri indo-europene: ablativul (separativul), instrumentalul și locativul [...]”, ceea ce „a determinat în bună măsură legarea lui frecventă

manifestate în cuvintele acordate (în gen, număr și caz)”, ce „generează aceeași funcție - atribut adjectival”; (3) cazuri de ordinul III, „cele cerute de prepoziții; se manifestă în substantive și pronume [...], conform regimului prepozițiilor” (Drașoveanu, 1997d, p. 94-96; vezi și Drașoveanu, 1997 c, p. 80-81). Precizăm, de asemenea, că în situația unor structuri ce ridică probleme la nivelul identificării cazului „cu baltă din las-o baltă, [...] «non-casus» sau «casus generalis»”, altfel spus, atunci cînd există o ,identitate de cazuri, în afara acordului” (Drașoveanu, 1997e, p. 118), sintacticianul clujean rezolvă dificultatea prin avansarea și „relevarea unui nou mijloc de exprimare a raporturilor sintactice - variația cazuală concomitentă sau flexiunea cazuală secundă”, ce reprezintă „unul din mijloacele subordonării intrapropoziționale, altul decît acordul” (Drașoveanu, 1997h, p. 286; vezi și Drașoveanu, 1997f, p. 128-130).

Însă, spre deosebire de D.D. Drașoveanu, acestea consideră întotdeauna elementul predicativ suplimentar și numele predicativ drept cazuri de ordin 2, realizate prin acord, indiferent dacă sînt exprimate prin substantive sau adjective.

${ }^{2}$ În concepția lui D.D. Drașoveanu, elementul predicativ suplimentar și numele predicativ se subordonează numai substantivalului, dar în prezența verbului („teza monosubordonării”). Totuși, în ciuda faptului că ambele formează sintagmă cu verbul, niciunul nu se subordonează acestuia („teza sintagmelor condiționate”). Ba mai mult, elementul predicativ suplimentar și numele predicativ se definesc prin termenul „asociat”, care înseamnă altceva decît subordonat, numele predicativ fiind un atribut la distanță dislocat prin verbul asemantic a fi, în timp ce elementul predicativ suplimentar este un atribut la distanţă dislocat printr-un verb semantic (vezi, în acest sens, Drașoveanu, $1997 \mathrm{~g}$ ).

${ }^{3}$ Concepînd sintagma ca „unitatea—și minimală, și maximală—a sintagmicii, categoria ei generală care-și subordonează ca specii, și propoziția, şi fraza”, D.D. Drașoveanu o definește drept grupul de două lexeme, într-o anumită ipostază a lor, şi relația dintre ele (termen - relație - termen), unde relația „nu rezultă din prezența termenilor, ci termenii rezultă din prezența relației” (cf. Drașoveanu, 1997 a, p. 40, 42).

În consecință, în funcție de tipul relatemului-coordonator sau subordonator, ce sînt în fapt „particularizări ale aceluiași general”-, D.D. Drașoveanu identifică o sintagmă subordonativă (= termen regent - relație subordonantă - termen subordonat), respectiv o sintagmă coordonativă (= termen anterior - relație coordonativă - termen posterior) (vezi Drașoveanu, 1997b, p. 50-51). 
prin prepoziție de termenul regent, din nevoia de dezambiguizare, dar el nu a încetat să funcționeze singur, sintetic [...].” (p. 129).

Al doilea volum tratează sintaxa modurilor. Structurat în două părți însoțite de două anexe, volumul debutează cu o serie de consideraţii generale (p. 9-11) pe marginea „categoriilor gramaticale la care el [verbul, precizarea noastră - M.A.] participă: aspectul, felul acțiunii, modul, timpul, diateza, persoana și numărul.” (p. 9).

Partea I, intitulată Modurile personale (p. 13154), așa cum titlul indică, este consacrată modurilor personale „în care va fi încadrată și folosirea specială a infinitivului ca substitut al unor moduri personale; cazul infinitivului istoric / narativ și al celui exclamativ / interogativ" (p. 11). Luînd în discuție tipologia propozițiilor și distingînd între propoziții principale (p. 28-30) și propoziții subordonate (p. 33-39), autoarele realizează, prin identificarea și explicarea situațiilor în care se manifestă, o trecere în revistă a valorilor modurilor și timpurilor verbale în propozițiile principale (p. 15-27), respectiv în propozițiile subordonate fără conectiv (p. 39-41) și cele subordonate cu conectiv (p. 42-154), o atenție particulară fiind acordată propozițiilor conjuncționale necircumstanțiale (p. 63-73) și circumstanţiale (p. 73-154).

Partea a II-a, intitulată Modurile nepersonale (p. 155-205), abordează acele „forme nominale ale verbului, care nu au mărci morfologice pentru categoria persoanei” (p. 155). Evidențiind complexitatea structurii modurilor nepersonale ilustrată prin dubla valoare, și anume verbală și nominală „substantivală—pentru infinitiv, gerunziu și supin—sau adjectivală—pentru participiu și gerundiv" (p. 155), ce are urmări atît în plan morfologic, cît și sintactic, lingvistele realizează inventarul situațiilor specifice infinitivului (p. 157-173), participiului (p. 174-186), gerunziului (p. 187-192), gerundivului (p. 193-202) și supinului (p. 203-205).

Două anexe însoțesc expunerea modurilor verbale: prima ia în discuție concordanţa timpurilor (p. 207-211) în propozițiile subordonate cu predicatul la indicativ, respectiv la conjunctiv, în timp ce a doua tratează stilul indirect (p. 213-215).

Însoțită de un solid aparat critic, reperabil atît în numeroasele note de subsol, cît și în listele bibliografice aferente celor două volume, Sintaxa latină elaborată de Frieda Edelstein, Carmen Fenechiu și Dana LaCourse Munteanu este o lucrare ce și-a atins obiectivul. Logică, clară și coerentă prin maniera matematică de dispunere a faptelor de limbă, Sintaxa latină dobîndește o dublă valoare: pe de o parte, concret științifică, prin soliditatea informației și a argumentării putînd fi consultată și înțeleasă nu doar de către specialiști, ci şi de către nespecialiști și, pe de altă parte, simbolică, prin înscrierea sa în modelul impus de creatorul sintaxei clujene, profesorul D.D. Drașoveanu, ale cărui concepte, idei, taxonomiisintagmă, relație, variație cazuală concomitentă, tipologia cazurilor etc.-sînt folosite de autoare, cu anumite diferențe, în prezentarea sintaxei latine.

\section{Bibliografie}

Drașoveanu, D.D. (1994-1995). Sintaxa limbii române, curs ținut la Facultatea de Litere, Universitatea „Babeș-Bolyai”, Cluj-Napoca. Draşoveanu, D.D. (1997). Teze și antiteze în sintaxa limbii române, Editura Clusium, Cluj-Napoca, 1997.

Drașoveanu, D.D. (1997a). Relația - creatorul termenilor, în Drașoveanu, 1997, p. 40-44.

Drașoveanu, D.D. (1997b). Relația - organizatorul termenilor, în Drașoveanu, 1997, p. 45-51.

Drașoveanu, D.D. (1997c). Categoriile gramaticale de relație ale limbii române, în Drașoveanu, 1997, p. 78-93.

Drașoveanu, D.D. (1997d). O clasificare a cazurilor cu aplicare în problema posesivelor, în Drașoveanu, 1997, p. 94-100.

Drașoveanu, D.D. (1997e). Variație cazuală concomitentă, în Drașoveanu, 1997, p. 113-118.

Drașoveanu, D.D. (1997f). Nominativul și acuzativul - schițe sintactice cu adnotări, în Drașoveanu, 1997, p. 119-130.

Drașoveanu, D.D. (1997g). Predicatul. Definiție. Clasificare - desinențial și intonațional, în Drașoveanu, 1997, p. $195-208$.

Drașoveanu, D.D. (1997h). Postfață, în Drașoveanu, 1997, p. 284-286. 